\title{
An application of the Finite Difference Method for Solving the Mass Spring System Equation
}

\author{
Suatu Penerapan Metode Beda Hingga Untuk Menyelesaikan \\ Persamaan Sistem Pegas Massa
}

\author{
Gabariela Purnama Ningsi ${ }^{* 1}$, Fransiskus Nendi ${ }^{2}$,Lana Sugiarti ${ }^{* 3}$
}

\begin{abstract}
The numerical method is one method that can be used to solve differential equations, both differential equations that are easy or difficult to solve analytically. The solution obtained from the calculation results is an approximate solution or a solution that approaches an analytic solution, not an analytic solution. That is, in solving differential equations numerically, there is always an error. In this paper, an analytical solution is described and described and the application of different methods in solving a damped mass spring system with a known limit value. The error between the analytic and numerical solutions obtained is very small.
\end{abstract}

Keywords: Numerical Method, Finite Difference Method, Mass Spring System, Error

\begin{abstract}
Abstrak
Metode numerik merupakan salah satu metode yang dapat digunakan untuk menyelesaikan persamaan diferensial, baik persamaan diferensial yang mudah maupun yang sulit untuk diselesaikan secara analitik. Solusi yang diperoleh dari hasil perhitungan merupakan sebuah solusi perkiraan atau solusi yang mendekati solusi analitik, bukan merupakan solusi analitik. Artinya, dalam menyelesaikan persamaan diferensial secara numerik, selalu terdapat error. Dalam paper ini dijelaskan dan diuraikan penyelesaian secara analitik dan penerapan metode beda hinggadalam menyelesaikan sistem pegas massa teredam dengan nilai batas yang diketahui. Error antara solusi analitik dan numerik yang diperoleh sangat kecil.
\end{abstract}

Kata kunci: Metode numerik, Metode Beda Hingga, Sistem Pegas Massa, Error

\section{Pendahuluan}

Matematika merupakan salah satu bidang ilmu yang manfaatnya sangat besar dalam seluruh sektor kehidupan, baik dalam bidang ekonomi, teknik, kedokteran, sosial, maupun bidang yang lain [1]. Salah satu kajian dalam ilmu matematika yang juga berkaitan dalam sektor kehidupan dan bidang ilmu lain adalah kajian tentang persamaan diferensial. Persamaan diferensial dapat diterapkan dalam berbagai bidang ilmu dalam matematika maupun bidang ilmu lain seperti 


\section{Gabariela Purnama Ningsi, Fransiskus Nendi, Lana Sugiarti}

teknik, ekonomi dan bidang kesehatan [2]. Salah satu masalah dalam bidang teknik yang dapat diselesaikan dengan ilmu matematika adalah masalah tentang sistem pegas massa.

Dalam menyelesaikan masalah sistem pegas massa ini, terlebih dahulu dimodelkan masalah tersebut menjadi sebuah model matematika. Model matematika dibentuk dari hasil deksripsi perilaku masalah nyata ke dalam bahasa matematika, kemudian bentuk matematika tersebut diselesaikan secara simbolik, dan solusinya ditafsirkan kembali untuk menjelaskan perilaku masalah yang sebenarnya [3]. Model matematika yang akan diperoleh berbentuk persamaan diferensial. Untuk mencari solusi persamaan diferensial yang dibentuk, penyelesaiannya dapat dilakukan secara analitik dan metode numerik. Dalam menyelesaikan persamaan diferensial yang memiliki bentuk yang rumit sangat sulit diselesaikan secara analitik, maka alternatif penyelesaian persamaan diferensial dilakukan dengan menggunakan metode numerik.

Metode numerik [4] merupakan sebuah teknik untuk mencari solusi dari masalah yang sudah dimodelkan dalam bentuk matematis. Solusi yang dihasilkan dalam proses penyelesaian tersebut akan berupa sebuah solusi perkiraan atau solusi yang mendekati solusi analitis. Terdapat berbagai metode numerik yang dapat kita gunakan dalam menyelesaikan masalah, tergantung dari jenis dan tujuan masalah yang ingin diselesaikan tersebut. Salah satu metode numerik yang dapat digunakan untuk menyelesaikan persamaan sistem pegas massa adalah metode beda hingga.

Metode beda hingga merupakan salah satu metode numerik yang dapat digunakan untuk menyelesaikan persoalan teknis dan masalah matematika dari suatu gelaja fisis, dimana prinsipnya adalah mengganti turunan yang terdapat dalam persamaan diferensial dengan diskritisasi beda hingga berdasarkan deret Taylor [5].

Metode beda hingga akan digunakan untuk menyelesaikan persamaan diferensial yang telah dimodelkan dengan menerapkan beberapa kondisi batas yang telah ditetapkan sebelumnya. Karena solusi dari hasil perhitungan numerik merupakan sebuah perkiraan atau solusi pendekatan, maka akan ditemukan galat perhitungan numerik. Metode beda hingga telah banyak digunakan oleh para peneliti terdahulu untuk menyelesaikan persoalan dunia nyata. Adapun beberapa penelitian yang telah dilakukan adalah penelitian yang dilakukan oleh Hasan, dkk. yang membahas tentang "penerapan metode beda hingga pada model matematika aliran banjir dari persamaan saint venant" [5], penelitian yang dilakukan oleh Bambang yang membahas tentang "aplikasi metode beda hingga skema eksplisit pada persamaan konduksi panas" [6]. Selain itu, terdapat juga skripsi yang ditulis oleh Nursyamsu [7] pada tahun 2013 yang membahas tentang " Penentuan Harga Opsi untuk Model Black Scholes Menggunakan Metode Beda Hingga". Berdasarkan penelitian terdahulu tersebut, maka peneliti tertarik untuk membuat penelitian tentang penerapan metode beda hingga dalam menyelesaikan persamaan sistem pegas massa.

\section{Tinjauan Pustaka}

\section{a. Metode Beda Hingga}

Metode Beda Hingga merupakan salah satu metode numerik yang umum digunakan untuk menghitung pendekatan turunan dari sebuah fungsi. Dalam metode bedahingga, turunan dari setiap persamaan diferensial akan diubah kedalam bentuk persamaan differensil dengan menerapkan formula deret Taylor.

Dalam [8] dikatakan bahwa, jika $f(x)$ serta semua turunannya $f^{\prime}(x), f^{\prime \prime}(x), f^{\prime \prime \prime}(x), \ldots$, di dalam selang $[a, b]$ dan $x_{0} \in[a, b]$, maka nilai $x$ di mana $x \in[a, b]$ di sekitar $x_{0}$ dapat diekspansi ke dalam deret Taylor yaitu sebagai berikut:

$$
f(x)=f\left(x_{0}\right)+f^{\prime}\left(x_{0}\right) \frac{x-x_{0}}{1 !}+\frac{\left(x-x_{0}\right)^{2}}{2 !} f^{\prime \prime}\left(x_{0}\right)+\cdots+\frac{\left(x-x_{0}\right)^{m}}{m !} f^{(m)}\left(x_{0}\right)+\cdots .
$$




\section{Gabariela Purnama Ningsi, Fransiskus Nendi, Lana Sugiarti}

Jika $x-x_{0}=h, a<x_{0}$, serta $x_{0}+h<b$, maka $f(x)$ maka persamaan (1.1) akan menjadi persamaan berikut:

$$
f\left(x_{0}+h\right)=f\left(x_{0}\right)+\frac{h}{1 !} f^{\prime}\left(x_{0}\right)+\frac{h^{2}}{2 !} f^{\prime \prime}\left(x_{0}\right)+\cdots+\frac{h^{m}}{m !} f^{(m)}\left(x_{0}\right)+\cdots .
$$

Jika persamaan (1.2) di atas diperluas maju untuk menghitung nilai sesudah nilai sekarang maka formula deret Taylornya adalah deret Taylor dari sebuah fungsi $f(x+\Delta x)$ di sekitar titik $x$ diperoleh sebagai berikut [5]:

$$
f(x+\Delta x)=f(x)+f^{\prime}(x) \Delta x+\frac{f^{\prime \prime}(x)}{2 !} \Delta x^{2}+\frac{f^{\prime \prime \prime}(x)}{3 !} \Delta x^{3}+\cdots .
$$

Formula deret Taylor dari sebuah fungsi $f(x-\Delta x)$ di sekitar diperoleh sebagai berikut:

$$
f(x-\Delta x)=f(x)+f^{\prime}(x)(-\Delta x)+\frac{f^{\prime \prime}(x)}{2 !}(-\Delta x)^{2}+\frac{f^{\prime \prime \prime}(x)}{3 !}(-\Delta x)^{3}+\cdots .
$$

Dari persamaan (1.3) akan diperoleh turunan pertama seperti persamaan berikut:

$$
f^{\prime}(x)=\frac{f(x+\Delta x)-f(x)}{\Delta x}+o \Delta x
$$

Atau dari persamaan (1.4) diperoleh turunan pertama sebagai berikut:

$$
f^{\prime}(x)=\frac{f(x)-f(x-\Delta x)}{\Delta x}+O \Delta x
$$

Persamaan (1.5) merupakan turunan numerik bedamaju sedangkan persamaan (1.6) adalah turunan numerik beda mundur. Persamaan (1.5) dan (1.6) di atas merupakan turunan numerik orde pertama, dengan tingkat keakuratan tingkat 1. Selanjutnya dari persamaan (1.3) dan (1.4) diperoleh turunan numerik beda pusat dengan tingkat keakuratan tingkat 2, yaitu sebagai berikut:

$$
f^{\prime}(x)=\frac{f(x+\Delta x)-f(x-\Delta x)}{2 \Delta x}+O \Delta x^{2}
$$

Untuk memperoleh nilai pendekatan turunan kedua dapat dilakukan dengan cara menjumlahkan persamaan (1.3) dan (1.4) sehingga diperoleh:

Sehingga diperoleh:

$$
f(x+\Delta x)+f(x-\Delta x)=2 f(x)+f^{\prime \prime}(x) \Delta x^{2}+o \Delta x^{2}
$$

$$
f^{\prime \prime}(x)=\frac{f(x+\Delta x)-2 f(x)+f(x-\Delta x)}{\Delta x^{2}}+o \Delta x^{2}
$$

Persamaan (1.9) disebut turunan numerik kedua beda pusat.

Jika $x$ pada persamaan (1.5), (1.6), dan (1.7) di atas diganti dengan $x=x_{0}+i \Delta x$ dengan $i$ adalah bilangan bulat dan $f(x) \approx f\left(x_{0}+i \Delta x\right)$, maka persamaan (1.5), (1.6), dan (1.7) akan menjadi:

$$
\begin{gathered}
f^{\prime}=\frac{f_{i+1}-f_{i}}{\Delta x} \\
f^{\prime}=\frac{f_{i}-f_{i-1}}{\Delta x} \\
f^{\prime}=\frac{f_{i+1}-f_{i-1}}{2 \Delta x}
\end{gathered}
$$

Sedangkan persamaan (1.9) akan menjadi seperti berikut:

$$
f^{\prime \prime}=\frac{f_{i+1}-2 f_{i}+f_{i-1}}{\Delta x^{2}}
$$

Ketika persamaan $(1.10)-(1.13)$ diamati dalam selang interval $\left[x_{0}, x_{N}\right]$ maka dapat diperoleh 


\section{Gabariela Purnama Ningsi, Fransiskus Nendi, Lana Sugiarti}

$$
\Delta x=\frac{x_{N}-x_{0}}{N}
$$

adalah sebuah panjang interval yang membagi selang tersebut dalam $N$ bagian sama panjang.

\section{b. Sistem Pegas Massa}

Devaney [9] mengatakan bahwa bentuk umum persamaan diferensial orde dua adalah sebagai berikut:

$$
y^{\prime \prime}+a y^{\prime}+b y=G(t)
$$

Dengan $a$ dan $b$ adalah koefesien dari persamaan diferensial tersebut. Persamaan diferensial di atas merupakan sebuah persamaan diferensial orde dua non homogen dengan koefisien konstan. Jika $G(t)=0$, maka persamaan tersebut akan menjadi sebuah persamaan diferensial orde dua homogen. Persamaan diferensial biasa linear orde dua homogeny dengan koefisien konstan memiliki bentuk umum seperti berikut ini:

$$
y^{\prime \prime}+a y^{\prime}+b y=0
$$

Dimana $a$ dan $b$ merupakan konstanta sebarang.

Pada sistem pegas massa, kita dapat merumuskan atau memodelkan persamaan diferensial yang menyatakan posisi massa dengan memperhatikan gaya yang bekerja pada gerak massa tersebut. Jika sistem pegas massa yang dimaksud seperti pada gambar berikut:

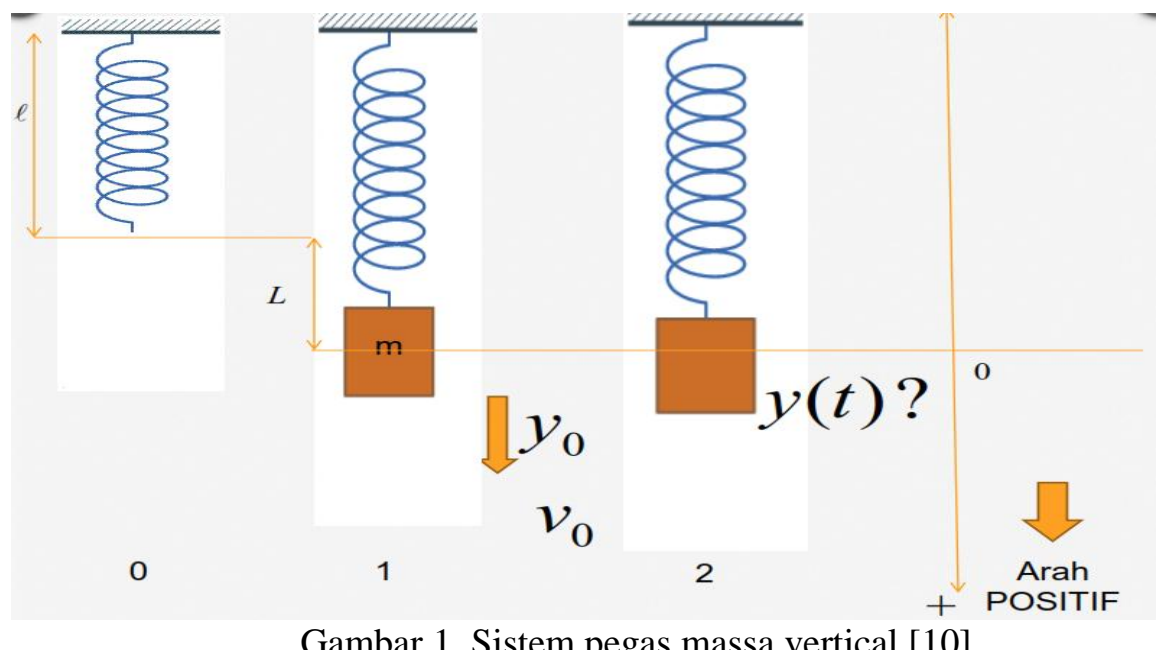

Gaya yang dihasilkan akibat pergerakan massa tersebut sesuai dengan Hukum II Newton yaitu sama dengan massa dikali dengan percepatannya, dapat ditulis [9]: $\sum F=m$. $a$, dengan $a=$ $\frac{d^{2} y}{d t^{2}}=y^{\prime \prime}$ dan $m$ adalah massa benda. Sehingga,

$$
\sum F=m \cdot y^{\prime \prime}
$$

Ada dua gaya yang bekerja pada massa tersebut [10], yaitu:

1) Gaya pegas. Hukum Hooke mengatakan bahwa gaya yang diberikan oleh pegas sebanding dengan perpindahan massa dari posisi diam, dapat ditulis:

$$
F_{p}=-k y, k>0
$$

dengan $\mathrm{k}$ adalah konstanta pegas, $\mathrm{y}$ adalah posisi massa.

2) Gaya gesek. Untuk gaya akibat gesekan ini kita asumsikan bahwa gaya tersebut sebanding dengan kecepatan gerak massa, yang dapat ditulis: 


$$
F_{g}=-b y^{\prime}
$$

dimana $b$ merupakan konstanta redaman atau gesekan dan $y^{\prime}$ merupakan kecepatan massa. Ada dua kasus untuk konstanta redaman yang dapat kita amati, yaitu:

a. Ketika $b=0$, maka tidak ada gesekan (maka massa tidak akan kembali ke posisi diam).

b. Ketika $b>0$, maka ada gesekan (massa akan kembali ke posisi diam atau posisi setimbang).

Karena gaya yang bekerja pada gerak massa adalah gaya pegas dan gaya gesek, maka dari persamaan (1.16), (1.17), dan (1.18) diperoleh besarnya gaya yang bekerja pada pergerakan massa tersebut adalah:

$$
\begin{gathered}
\sum F=m y^{\prime \prime} \\
F_{p}+F_{g}=m y^{\prime \prime} \\
-k y-b y^{\prime}=m y^{\prime \prime} \\
m y^{\prime \prime}+b y^{\prime}+k y=0
\end{gathered}
$$

Sehingga, diperoleh model persamaan diferensial homogen orde dua untuk sistem pegas massa yaitu:

atau

$$
m y^{\prime \prime}+b y^{\prime}+k y=0
$$

$$
m \frac{d^{2} y}{d t^{2}}+b \frac{d y}{d t}+k y=0
$$

Dimana, $b$ dan $k$ adalah parameter konstanta. Dengan:

$$
\begin{array}{ll}
y & : \text { besar perpindahan massa, } \\
m & : \text { massa benda yang digantungkan pada pegas, } \\
b & : \text { konstanta redaman pegas, } \\
k & : \text { konstanta pegas, } \\
y^{\prime} & : \text { kecepatan gerak massa. }
\end{array}
$$

\section{c. Penerapan Metode Beda Hingga Pada Sistem Pegas Massa}

Misalkan $y(t)$ merupakan penyelesaian dari persamaan (1.19) di atas dengan $\Delta t$ merupakan perubahan posisi massa, dimana akan diamati dalam selang interval $\left[t_{0}, t_{N}\right]$ selanjutnya interval tersebut dipartisi sehingga diperoleh: $t_{i}=t_{0}+i \Delta t$ dengan $i=1,2,3, \ldots$ dan

$$
\begin{gathered}
0=t_{0}<t_{0}<t_{0}<\cdots<t_{N} \\
\Delta t=\frac{t_{N}-t_{0}}{N}
\end{gathered}
$$

adalah sebuah panjang interval yang membagi selang tersebut dalam $N$ bagian sama panjang [11]. Berdasarkan persamaan (1.12), (1.13) dan (1.20) maka dapat diperoleh kedua persamaan berikut [12]:

$$
\begin{gathered}
y^{\prime}\left(t_{i}\right)=\frac{y\left(t_{i+1}\right)-y\left(t_{i-1}\right)}{2 \Delta t}+O\left(\Delta t^{2}\right) \\
y^{\prime \prime}\left(t_{i}\right)=\frac{y\left(t_{i+1}\right)-2 y\left(t_{i}\right)+y\left(t_{i-1}\right)}{\Delta t^{2}}+O\left(\Delta t^{2}\right)
\end{gathered}
$$

Jika, $y\left(t_{i}\right)=y_{i}, y\left(t_{i+1}\right)=y_{i+1}$, dan $y\left(t_{i-1}\right)=y_{i-1}$ maka persamaan (1.21) dan (1.22) akan menjadi:

$$
y_{i}^{\prime}=\frac{y_{i+1}-y_{i-1}}{2 \Delta t}+O\left(\Delta t^{2}\right)
$$




$$
y_{i}^{\prime \prime}=\frac{y_{i+1}-2 y_{i}+y_{i-1}}{\Delta t^{2}}+O\left(\Delta t^{2}\right)
$$

Berdasarkan persamaan (1.19), (1.20), (1.23) dan (1.24) di atas maka dapat diperoleh pendekatan turunan kedua dari sistem pegas massa yang telah dimodelkan sebagai berikut:

$$
\frac{y_{i+1}-2 y_{i}+y_{i-1}}{\Delta t^{2}}+\frac{b}{m}\left(\frac{y_{i+1}-y_{i-1}}{2 \Delta t}\right)+\frac{k}{m} y_{i}=0
$$

\section{Hasil Penelitian}

Persamaan diferensial orde dua pada sistem pegas massa biasanya dilengkapi dengan dua posisi awal dan kecepatan awal massa, yaitu:

$y(0)=y_{0}$, posisi massa ketika diam atau $t=0$, dan $y^{\prime}(0)=y^{\prime}{ }_{0}$, kecepatan awal massa ketika $t=0$. Agar pergerakan massa dapat digambarkan, maka digunakan variable baru, yaitu: $v=y^{\prime}$, maka $y^{\prime \prime}=v^{\prime}=-k y-b v$, atau dapat ditulis:

$$
\begin{gathered}
\frac{d y}{d t}=v \\
\frac{d^{2} y}{d t^{2}}=-k y-b v
\end{gathered}
$$

Dari persamaan (2.1) di atas, maka akan diperoleh grafik posisi dan kecepatan massa serta bidang fase pergerakan massa (diperoleh dengan menggunakan aplikasi DETools) seperti yang ditunjukan pada gambar berikut:

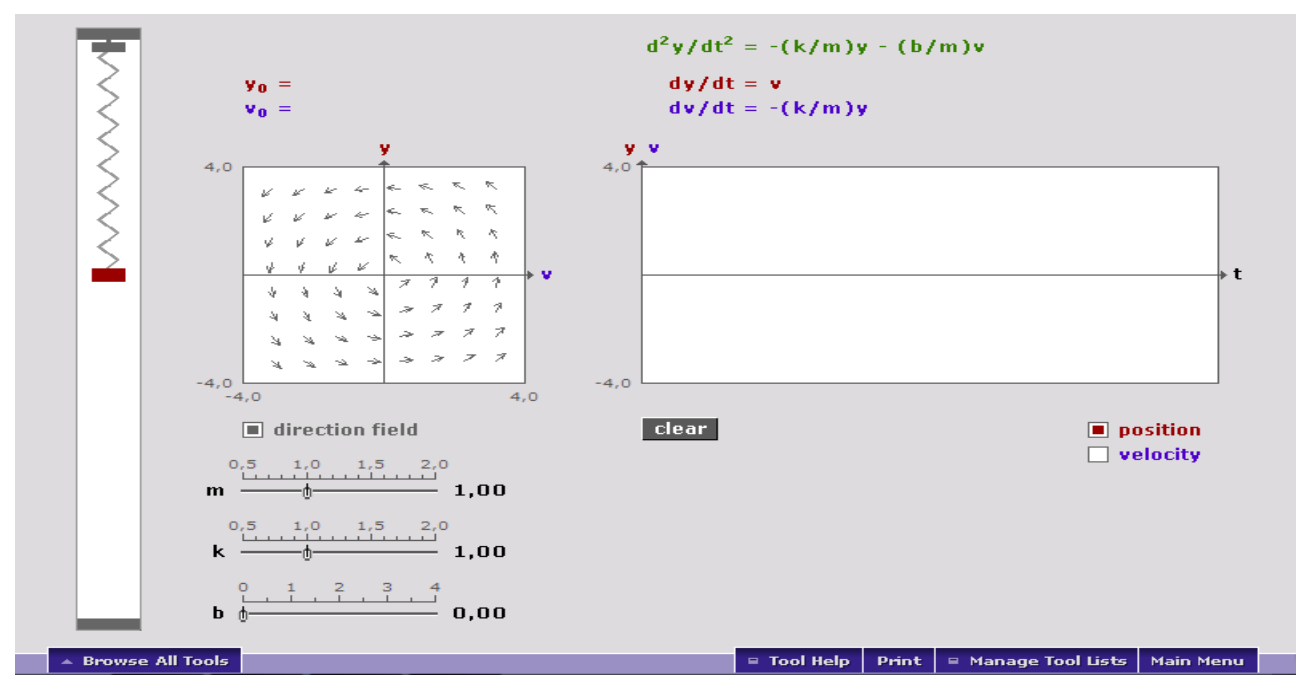

Gambar 2. Grafik posisi dan kecepatan massa serta bidang fase pergerakan massa

Terdapat dua kasus konstanta redaman yang dapat diamati dalam sistem pegas massa [9], yaitu:

1. Saat massa terus berosilasi, maka tidak ada gaya gesek dengan nilai $b=0$. Grafik posisi dan kecepatan massa serta bidang fase pergerakan massa akan terlihat seperti gambar berikut: 


\section{Gabariela Purnama Ningsi, Fransiskus Nendi, Lana Sugiarti}

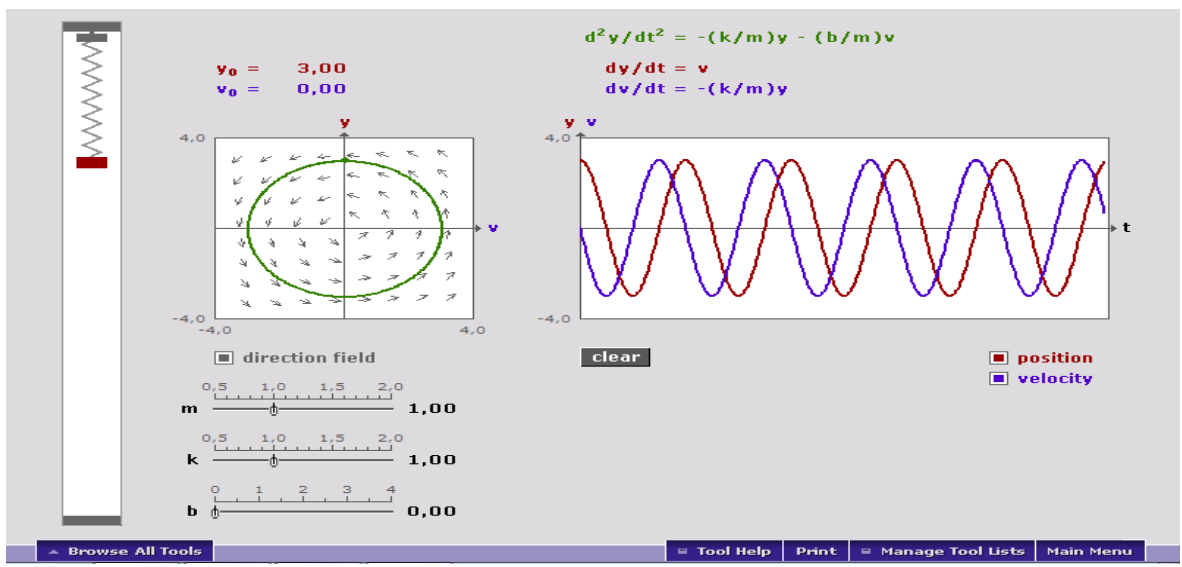

Gambar 3. Grafik posisi dan kecepatan massa serta bidang fase pergerakan massa ketika $b=0$

2. Saat massa dapat kembali ke posisi setimbang/diam atau berhenti berosilasi, hal ini terjadi ketika nilai $b>0$. Grafik posisi dan kecepatan massa serta bidang fase pergerakan massa akan terlihat seperti gambar berikut:

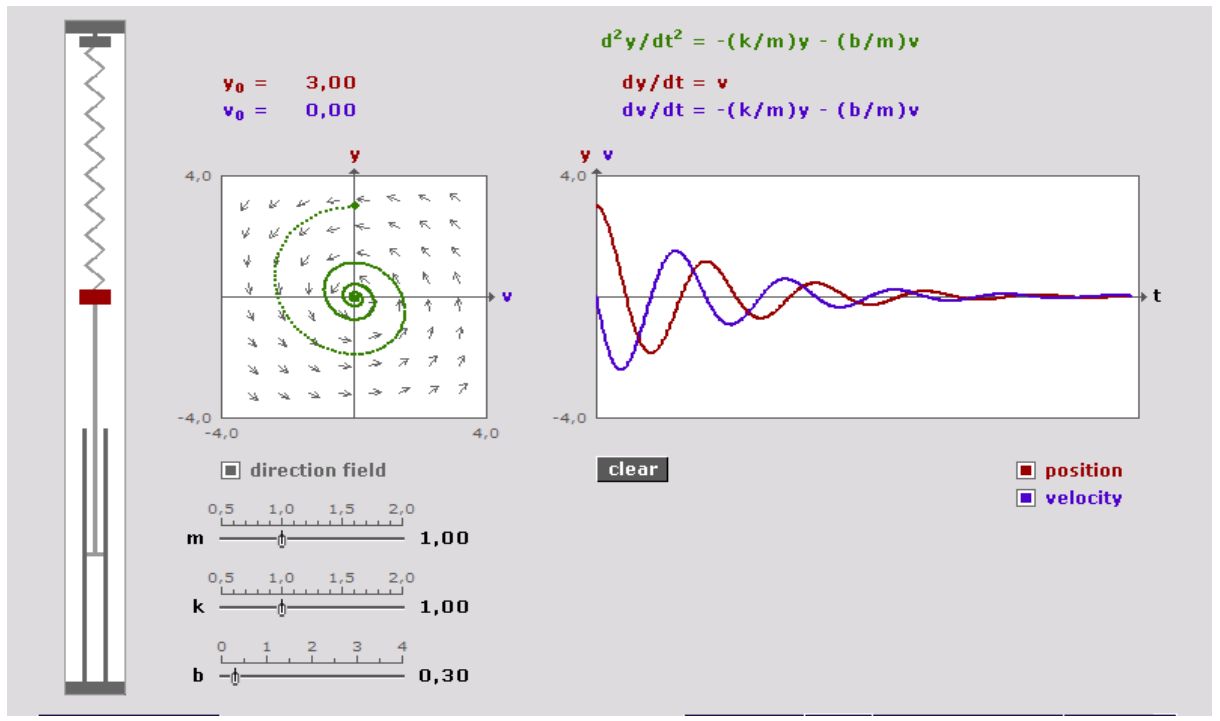

Gambar 4. Grafik posisi dan kecepatan massa serta bidang fase pergerakan massa ketika $b>0$

Dalam tulisan ini secara khusus dibahas tentang pergerakan massa ketika $b>0$, dimana pergerakan massa dipengaruhi oleh gaya gesek yang akhirnya akan berhenti berosilasi dan kembali ke posisi diam. Berdasarkan persamaan sistem pegas massa yang telah dimodelkan secara analitik dan numerik (metode beda hingga) seperti pada persamaan (1.19) dan (1.25) di atas dengan $b, m$ dan $k$ merupakan konstanta rill, maka akan dicari penyelesaian secara analitik dan numerik dari sistem pegas massa teredam. Karena tulisan ini hanya secara khusus membahas tentang pergerakan massa ketika $b>0$, maka penulis mengmbil nilai $b, m$ dan $k$ secara acak, kemudian melihat perilaku solusi ketika nilai $b, m$ dan $k$ berturut-turut $0.9,1.5$, dan 26.8, serta $t$ dihitung pada selang $[0,120]$ dengan panjang selang $N=24$. Berdasarkan informasi yang diketahui tersebut, maka akan dihitung $y(t)$ secara analitik dan numerik. 


\section{Gabariela Purnama Ningsi, Fransiskus Nendi, Lana Sugiarti}

\section{a. Penyelesaian sistem pegas massa teredam secara analitik}

Berdasarkan persamaan (1.19) dan nilai $b=0.9, m=1.5$ dan $k=26.8$ diperoleh persamaan berikut:

$$
1.5 y^{\prime \prime}+0.9 y^{\prime}+26.8 y=0
$$

Bentuk persamaan karakteristik dari persamaan (2.2) di atas adalah sebagai berikut:

$$
1.5 a^{2}+0.9 a+26.8=0
$$

Dengan $a \neq 0$. Akar dari persamaan (2.3) di atas adalah

$$
a_{1}=-0.3+4.216238 i \text { dan } a_{2}=-0.3-4.216238 i
$$

Sehingga solusi umum dari persamaan (2.4) adalah sebagai berikut:

$$
y(t)=e^{-0.3 t}\left(c_{1} \cos 4.216238 t+c_{2} \sin 4.216238 t\right)
$$

Jika diketahui nilai awal $y(0)=0.56$ dan $y^{\prime}(0)=10$ maka dapat diperoleh nilai $c_{1}$ dan $c_{2}$ sebagai berikut:

$$
c_{1}=0.56 \text { dan } c_{2}=2.411629
$$

Sehingga diperoleh solusi khusus dari persamaan (2.5) dengan nilai awal yang telah diketahui adalah sebagai berikut:

$$
y(t)=e^{-0.3 t}(0.56 \cos 4.216238 t+2.411629 \sin 4.216238 t)
$$

Hasil penyelesaian analitik dari persamaan (2.7) dapat dilihat pada tabel berikut:

Tabel 1. Nilai Analitik Osilasi Pegas teredam

ketika $b=0.9, m=1.5, k=26.8$ dan $y(0)=0.56$

\begin{tabular}{cccccccc}
\hline$t$ & $y(t)$ & $t$ & $y(t)$ & $t$ & $y(t)$ & $t$ & $y(t)$ \\
\hline 1 & -1.768641552206420 & 31 & -0.000192461767185 & 61 & -0.000000005391654 & 91 & 0.000000000002026 \\
2 & 0.940219060106037 & 32 & -0.000009733363242 & 62 & -0.000000015954442 & 92 & -0.000000000002532 \\
3 & 0.307445085593421 & 33 & 0.000112490917653 & 63 & 0.000000014212849 & 93 & 0.000000000000674 \\
4 & -0.732866897453655 & 34 & -0.000074006373463 & 64 & -0.000000001269390 & 94 & 0.000000000000914 \\
5 & 0.348215735791228 & 35 & -0.000009534160835 & 65 & -0.000000006904783 & 95 & -0.000000000001015 \\
6 & 0.156583592006190 & 36 & 0.000047340707043 & 66 & 0.000000005567109 & 96 & 0.000000000000214 \\
7 & -0.301554825486156 & 37 & -0.000028160440399 & 67 & -0.000000000137468 & 97 & 0.000000000000406 \\
8 & 0.126774003775306 & 38 & -0.000006117491424 & 68 & -0.000000002958328 & 98 & -0.000000000000404 \\
9 & 0.076073724621858 & 39 & 0.000019769896107 & 69 & 0.000000002162171 & 99 & 0.000000000000062 \\
10 & -0.123235467688281 & 40 & -0.000010587818097 & 70 & 0.000000000098425 & 100 & 0.000000000000178 \\
11 & 0.045176936277900 & 41 & -0.000003381578563 & 71 & -0.000000001256052 & 101 & -0.000000000000159 \\
12 & 0.035766427248101 & 42 & 0.000008195995006 & 72 & 0.000000000831969 & 102 & 0.000000000000015 \\
13 & -0.050022332325278 & 43 & -0.000003925391238 & 73 & 0.000000000102487 & 103 & 0.000000000000077 \\
14 & 0.015655415814644 & 44 & -0.000001729188931 & 74 & -0.000000000528886 & 104 & -0.000000000000063 \\
15 & 0.016409916451009 & 45 & 0.000003374025115 & 75 & 0.000000000316816 & 105 & 0.000000000000002 \\
16 & -0.020167001011486 & 46 & -0.000001430950223 & 76 & 0.000000000066785 & 106 & 0.000000000000033 \\
17 & 0.005219322910177 & 47 & -0.000000842349315 & 77 & -0.000000000220981 & 107 & -0.000000000000024 \\
\hline
\end{tabular}




\begin{tabular}{lcccccccc}
\hline 18 & 0.007386310702262 & 48 & 0.000001379493348 & 78 & 0.000000000119222 & 108 & -0.000000000000001 \\
19 & -0.008074535877748 & 49 & -0.000000510767487 & 79 & 0.000000000037181 & 109 & 0.000000000000014 \\
20 & 0.001641873541931 & 50 & -0.000000396799951 & 80 & -0.000000000091657 & 110 & -0.000000000000009 \\
21 & 0.003273264514315 & 51 & 0.000000560207466 & 81 & 0.000000000044247 & 111 & -0.000000000000001 \\
22 & -0.003209954636824 & 52 & -0.000000177387291 & 82 & 0.000000000019092 & 112 & 0.000000000000006 \\
23 & 0.000467812543821 & 53 & -0.000000182324012 & 83 & -0.000000000037750 & 113 & -0.000000000000004 \\
24 & 0.001431677700974 & 54 & 0.000000225958808 & 84 & 0.000000000016150 & 114 & -0.000000000000001 \\
25 & -0.001266609040465 & 55 & -0.000000059323904 & 85 & 0.000000000009326 & 115 & 0.000000000000002 \\
26 & 0.000107711567862 & 56 & -0.000000082163290 & 86 & -0.000000000015442 & 116 & -0.000000000000001 \\
27 & 0.000619152851887 & 57 & 0.000000090513488 & 87 & 0.000000000005774 & 117 & 0.000000000000000 \\
28 & -0.000495847619043 & 58 & -0.000000018753682 & 88 & 0.000000000004402 & 118 & 0.000000000000001 \\
29 & 0.000009959675551 & 59 & -0.000000036446498 & 89 & -0.000000000006274 & 119 & 0.000000000000000 \\
30 & 0.000265101647947 & 60 & 0.000000036000647 & 90 & 0.000000000002010 & 120 & 0.000000000000000 \\
\hline
\end{tabular}

Dari tabel di atas, terlihat bahwa pegas berhenti berosilasi ketika waktu berada disekitar $t=120$. Nilai regangan maksimum yang terjadi berdasarkan perhitungan tersebut adalah berada pada persekitaran 2.328642. Solusi analitik yang diperoleh pada persamaan (2.7) dapat digambarkan dalam bentuk grafik dengan menggunakan software MATLAB seperti yang ditunjukan oleh gambar berikut:

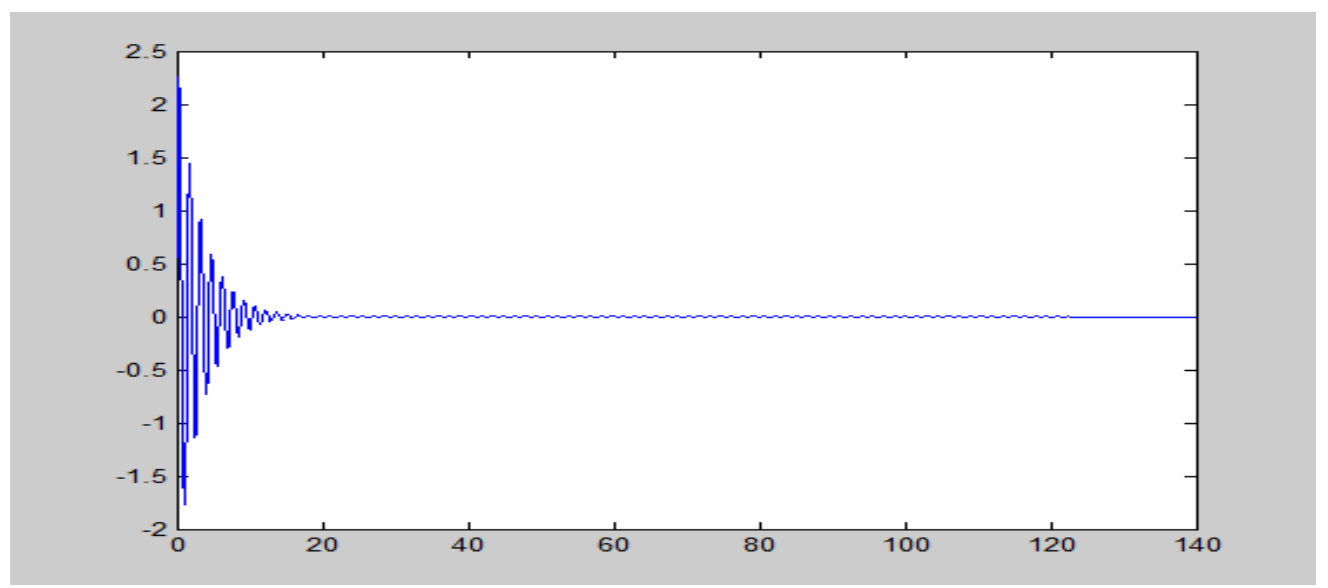

Gambar 5. Grafik Solusi Analitik Persamaan Getaran Pegas Teredam

\section{b. Penyelesaian sistem pegas massa teredam secara numerik}

Berdasarkan persamaan (1.23), (1.24), (1.26) dan $\Delta t=\frac{t_{120}-t_{0}}{N}$, maka $\Delta \mathrm{t}=\frac{120-0}{24}=5$, maka dapat dibentuk persamaan pendekatan turunan kedua dari persamaan sistem pegas massa yang telah dimodelkan dengan menggunakan metode beda hingga sebagai berikut:

$$
\begin{gathered}
1.5\left(\frac{y_{i+1}-2 y_{i}+y_{i-1}}{5^{2}}\right)+0.9\left(\frac{y_{i+1}-y_{i-1}}{2 \times 5}\right)+26.8 y_{i}=0 \\
-0.03 y_{i-1}+26.68 y_{i}+0.15 y_{i+1}=0
\end{gathered}
$$




\section{Gabariela Purnama Ningsi, Fransiskus Nendi, Lana Sugiarti}

Dari persamaan (2.8) di atas, dapat diperoleh matriks $A, B$, dan $C$ dengan $i=$ $(1,2,3, \ldots, 24)$ dan $y_{0}=0.56$ sebagai berikut:

$$
\begin{aligned}
& A=\left[\begin{array}{cccccc}
1 & 0 & 0 & 0 & \ldots & 0 \\
-0.03 & 26.68 & 0.15 & 0 & \ldots & 0 \\
0 & -0.03 & 26.68 & 0.15 & \ldots & 0 \\
0 & 0 & -0.03 & 26.68 & \ldots & 0 \\
\vdots & \vdots & \vdots & \vdots & \ddots & \vdots \\
0 & 0 & 0 & 0 & \ldots & 1
\end{array}\right] \text {, matriks berordo } 25 \text { x } 25 \\
& B=\left[\begin{array}{c}
y_{0} \\
y_{1} \\
y_{2} \\
y_{3} \\
y_{4} \\
\vdots \\
y_{24}
\end{array}\right], \text { matriks berordo } 25 \times 1 \\
& C=\left[\begin{array}{c}
0.56 \\
0 \\
0 \\
0 \\
0 \\
\vdots \\
0
\end{array}\right] \text {, matriks berordo } 25 \times 1
\end{aligned}
$$

Dengan menggunakan MATLAB dapat diperoleh nilai matriks $B$ berdasarkan persamaan (2.8), (2.9), dan (2.10) di atas seperti yang ditunjukan pada tabel berikut:

Tabel 2. Solusi Numerik menggunakan metode beda hingga Osilasi Pegas teredam ketika $b=0.9, m=1.5, k=26.8$ dan $y_{0}=0.56$ dengan rentangan selang $\Delta t=5$

\begin{tabular}{cccc}
\hline$i$ & $y_{i}$ & $i$ & $y_{i}$ \\
\hline 1 & 0.000629681176727 & 13 & 0.000000000000000 \\
2 & 0.000000708032829 & 14 & 0.000000000000000 \\
3 & 0.000000000796134 & 15 & 0.000000000000000 \\
4 & 0.000000000000895 & 16 & 0.000000000000000 \\
5 & 0.000000000000001 & 17 & 0.000000000000000 \\
6 & 0.000000000000000 & 18 & 0.000000000000000 \\
7 & 0.000000000000000 & 19 & 0.000000000000000 \\
8 & 0.000000000000000 & 20 & 0.000000000000000 \\
9 & 0.000000000000000 & 21 & 0.000000000000000 \\
10 & 0.000000000000000 & 22 & 0.000000000000000 \\
11 & 0.000000000000000 & 23 & 0.000000000000000 \\
12 & 0.000000000000000 & 24 & 0.000000000000000 \\
\hline
\end{tabular}

Dari tabel 2 di atas, dapat dilihat bahwa pegas akan berhenti berosilasi ketika nilai $i=6$. Jika tabel 1 di atas dibuat dalam rentangan skala 5, maka akan diperoleh tabel berikut: 


\section{Gabariela Purnama Ningsi, Fransiskus Nendi, Lana Sugiarti}

Tabel 3. Nilai Analitik Osilasi Pegas teredam ketika $b=0.9, m=1.5, k=26.8$ dan $y_{0}=0.56$

\begin{tabular}{cccc}
\hline$t$ & $y(t)$ & $t$ & $y(t)$ \\
\hline 5 & 0.348215735791228 & 65 & -0.000000006904783 \\
10 & -0.123235467688281 & 70 & 0.000000000098425 \\
15 & 0.016409916451009 & 75 & 0.000000000316816 \\
20 & 0.001641873541931 & 80 & -0.000000000091657 \\
25 & -0.001266609040465 & 85 & 0.000000000009326 \\
30 & 0.000265101647947 & 90 & 0.000000000002010 \\
35 & -0.000009534160835 & 95 & -0.000000000001015 \\
40 & -0.000010587818097 & 100 & 0.000000000000178 \\
45 & 0.000003374025115 & 105 & 0.000000000000002 \\
50 & -0.000000396799951 & 110 & -0.000000000000009 \\
55 & -0.000000059323904 & 115 & 0.000000000000002 \\
60 & 0.000000036000647 & 120 & 0.000000000000000 \\
\hline
\end{tabular}

c. Perbandingan nilai solusi analitik dan solusi numerik dengan menggunakan metode beda hingga

Berdasarkan Tabel 2 dan Tabel 3 di atas maka dapat diperoleh nilai perbandingan antara solusi analitik dan solusi numeri dengan menggunakan metode beda hingga sebagai berikut:

Tabel 4. Perbandingan Nilai solusi Analitik dan Numerik Osilasi Pegas Teredam ketika $b=0.9, m=1.5$, dan $k=26.8$ dengan menerapkan metode beda hingga

\begin{tabular}{ccccc}
\hline$t$ & $y(t)$ & $\mathrm{I}$ & $y_{i}$ & Error \\
\hline 0 & 0.560000000000000 & 0 & 0.560000000000000 & 0.000000000000000 \\
5 & 0.348215735791228 & 1 & 0.000629681176727 & 0.347586054614501 \\
10 & -0.123235467688281 & 2 & 0.000000708032829 & 0.123236175721110 \\
15 & 0.016409916451009 & 3 & 0.000000000796134 & 0.016409915654875 \\
20 & 0.001641873541931 & 4 & 0.000000000000895 & 0.001641873541036 \\
25 & -0.001266609040465 & 5 & 0.000000000000001 & 0.001266609040466 \\
30 & 0.000265101647947 & 6 & 0.000000000000000 & 0.000265101647947 \\
35 & -0.000009534160835 & 7 & 0.000000000000000 & 0.000009534160835 \\
40 & -0.000010587818097 & 8 & 0.000000000000000 & 0.000010587818097 \\
45 & 0.000003374025115 & 9 & 0.000000000000000 & 0.000003374025115 \\
50 & -0.000000396799951 & 10 & 0.000000000000000 & 0.000000396799951 \\
55 & -0.000000059323904 & 11 & 0.000000000000000 & 0.000000059323904 \\
60 & 0.000000036000647 & 12 & 0.000000000000000 & 0.000000036000647 \\
65 & -0.000000006904783 & 13 & 0.000000000000000 & 0.000000006904783 \\
70 & 0.000000000098425 & 14 & 0.000000000000000 & 0.000000000098425 \\
\hline
\end{tabular}




\begin{tabular}{ccccc}
\hline 75 & 0.000000000316816 & 15 & 0.000000000000000 & 0.000000000316816 \\
80 & -0.000000000091657 & 16 & 0.000000000000000 & 0.000000000091657 \\
85 & 0.000000000009326 & 17 & 0.000000000000000 & 0.000000000009326 \\
90 & 0.000000000002010 & 18 & 0.000000000000000 & 0.000000000002010 \\
95 & -0.000000000001015 & 19 & 0.000000000000000 & 0.000000000001015 \\
100 & 0.000000000000178 & 20 & 0.000000000000000 & 0.000000000000178 \\
105 & 0.000000000000002 & 21 & 0.000000000000000 & 0.000000000000002 \\
110 & -0.000000000000009 & 22 & 0.000000000000000 & 0.000000000000009 \\
115 & 0.000000000000002 & 23 & 0.000000000000000 & 0.000000000000002 \\
120 & 0.000000000000000 & 24 & 0.000000000000000 & 0.000000000000000 \\
\hline
\end{tabular}

\section{Kesimpulan}

Berdasarkan hasil yang telah diperoleh, dapat disimpulkan bahwa metode beda hingga dapat menyelesaikan persamaan sistem pegas massa. Hasil perhitungan secara analitik menujukan bahwa panjang regangan maksimum pegas adalah 2.328642 dan pegas akan berhenti berosilasi ketika $t=120$. Sedangkan hasil perhitungan secara numerik menunjukan bahwa panjang regangan maksimum pegas adalah 0.55937 dan pegas akan berhenti berosilasi ketika $i$ berada disekitar $i=6$. Error antara penyelesaian analitik dengan penyelesaian numerik sangat kecil.

\section{Daftar Pustaka}

[1] Haberman R., 1998. Mathematical Models: Mechanical Vibrations, Population Dynamics, and Traffic Flow. SIAM, Philadelphia.

[2] Gabariela Purnama N., Sudi, M., 2019. Penerapan Metode Runge-Kutta dan Iterasi Variasional dalam Simulasi Transmisi Tuberkulosis. Limits: Journal of Mathematics and Its Applications, Vol. 16, No. 2, hal. 147-157.

[3] Haines, C., \& Crouch, R., 2007. Mathematical Modelling and applications: Ability and competence frameworks. In W. Blum, P. L. Galbraith, H. Henn, \& M. Niss (Eds.), Moddeling and Aplications in Mathematics Education: The $14^{\text {th }}$ ICMI Study, (pp. 417-424). New York: Springer.

[4] Triatmodjo B., 2002. Metode Numerik. Beta Offset, Yogyakarta.

[5] Hasan, dkk., 2016. Penerapan Metode Beda Hingga pada Model Matematika Aliran Banjir dari Persamaan Saint Venant. Zeta - Math Journal, Vol. 2, No. 1, hal. 6-12.

[6] Bambang, A. S., 2015. Aplikasi Metode Beda Hingga Skema Eksplisit Pada Persamaan Konduksi Panas. Journal Math Educator Nusantara, Vol. 1, No. 1, hal. 41-46.

[7] Nursyamsu, T., 2013. Penentuan Harga Opsi untuk Model Black Scholes Menggunakan Metode Beda Hingga. Skripsi Jurusan Matematika Universitas Islam Negeri Alauddin Makasar.

[8] Forsyth, G., \& Wasow, W., 1960. Finite Difference Methods for Partial Differential Equations. Wiley. 


\section{Gabariela Purnama Ningsi, Fransiskus Nendi, Lana Sugiarti}

[9] Devaney, R., 2011. Mastering Differential Equations: The Visual Method. THE GREAT COURSES, Virginia.

[10] Wuryansari Muharini K., 2015. Bahan Ajar Pemodelan Matematika. Program Studi Matematika, Universitas Brawijaya

[11] Langtangen, H., \& Linge, S., 2016. Finite Difference Computing with PDEs- A Modern Software Approach. Released under CC Attribution 4.0 license.

[12] Duffy, D., 2006. Finite Difference Methods in Financial Engineering, A Partial Differential Equation Approach. Published by John Wiley \& Sons Ltd, The Atrium, Southern Gate, Chichester, England. 